Article

\title{
Introducing TED Talks as a Pedagogical Resource in Sport Management Education through YouTube and LinkedIn
}

\author{
Samuel López-Carril *(1), Vicente Añó (1) and María Huertas González-Serrano \\ Department of Physical Education and Sports, Faculty of Physical Activity and Sport Sciences, \\ Universitat de València, 46010 Valencia, Spain; vicent.anyo@uv.es (V.A.); m.huertas.gonzalez@uv.es (M.H.G.-S.) \\ * Correspondence: samuel.lopez@uv.es
}

Received: 7 November 2020; Accepted: 3 December 2020; Published: 5 December 2020

check for updates

\begin{abstract}
The COVID-19 pandemic has affected the educational sector, pushing it towards teaching-learning methodologies where the online aspect takes on special importance. In this sense, social media are tools that facilitate the creation of meaningful and sustainable learning environments. This study shares an educational experience where TED (Technology, Entertainment, Design) Talks are introduced as a pedagogical resource through YouTube and LinkedIn in a sport management course. A total of five TED Talks are viewed and discussed by the students in order to develop their professional profile, assisted by a set of initial questions posed by faculty. To assess the impact of the experience, a new scale is created and then validated. The analyses performed reflected the unidimensional nature of this scale, explaining the $64.36 \%$ of the variance, and presenting good psychometric properties $(\alpha=0.95)$. Furthermore, the results obtained reflect the educational potential of TED Talks in the context of sport management, with increases in the averages of all the items from the scale, with significant $(p<0.05)$ increases in six of them. Both the new validated instrument and the shared pedagogical proposal can be valuable to guide and evaluate future educational experiences which introduce TED Talks as a pedagogical resource in sport management education.
\end{abstract}

Keywords: TED Talks; social media; YouTube; LinkedIn; sport management; professional skills; online learning; digital technologies; scale validation; sustainable Higher Education

\section{Introduction}

Social media is one of the most outstanding technological phenomena in people's lives, having become an integral part of our society [1,2]. These types of tools are defined by López-Carril, Añó and Villamón [3] as "an umbrella concept that embraces communicative tools, based on internet and new media technologies, that allow organisations and/or individuals to interact, exchanging information and content generated individually or shared, in real time or asynchronously" (p. 581), and are reshaping the nature of the process of communication between individuals both within and outside organisations [4]. Indeed, increasingly, people see social media as an important part of their lives and are more willing to bring their interactions to these kinds of platforms [5]. Furthermore, these tools are one of the most vital sources of information used by people to receive the latest news or events [6].

The field of education has not been unaffected by the rise of social media, penetrating these tools in many domains of educational practices and processes [7]. In this sense, several studies have already studied their incorporation into university classes (e.g., [8-11]), underlining its positive impact on a wide range of areas linked to the teaching-learning process (e.g., student class engagement, sense of community, student-teacher interaction, collaborative learning, dissemination of information, academic performance, creativity). Nevertheless, as stated by Manca [12] and López-Carril, Anagnostopoulos 
and Parganas [13], the majority of those studies are focused on assessing the educational potential of Facebook and Twitter. Thus, other very popular social media in society that may offer valuable teaching-learning opportunities (e.g., Instagram, LinkedIn, TikTok, WhatsApp and YouTube), have received limited attention from the academic community. Therefore, it is worthwhile to conduct further targeted studies that explore the potential of these understudied social media, providing recommendations for its possible use to the educational community.

On the other hand, the worldwide COVID-19 pandemic has led to some temporary restrictions or limitations on citizens' rights (e.g., travel restrictions, employment constraints, quarantines and lockdowns) that have challenged the dynamics and structure of the educational system [14]. Higher education institutions have had to quickly shift from face-to-face to online and digital educational formats, forcing both teachers and students to communicate exclusively online for academic-related purposes $[15,16]$. In this uncertain context, sustaining the quality of education has been a major concern for the entire education community [17]. In this sense, digital technologies have been a fundamental element in sustaining educational dynamics during the development of the pandemic [18]. For instance, social media have undoubtedly been a pillar in creating direct channels of communication between students and teachers. Therefore, social media can be a helpful option to generate sustainable learning environments for the development of course content, which enable education to be continued regardless of possible physical restrictions associated with the evolution of the pandemic. In addition, the pandemic has come at a time of great proliferation of educational sources available on the internet at the disposal of the teaching community (e.g., videos, wikis, massive open online courses (MOOCs), podcasts, software applications, games). Within this wide and diverse group of educational resources available online, TED Talks stand out because of their popularity and their transversality in view of being incorporated into university courses [19].

TED (Technology, Entertainment, Design) Talks are a variety of recorded conference presentations on wide range of diverse topics (e.g., education, politics, technology, health, communication, science, business), where a speaker shares their knowledge in a maximum duration of 18 minutes, with the aim to inspire and stimulate the audience [20]. These videos are available free of charge both on the official website (https://www.ted.com/) and on YouTube since 2006 [21], with many of them surpassing a million views. Given its popularity, and its ability to capture the attention of students, some teaching faculty members have incorporated TED Talks as a teaching resource into their classes, creating new learning experiences (e.g., [22-24]), reporting positive results in terms of student learning. Nevertheless, so far no studies have been published that collect educational experiences where TED Talks have been introduced into sport management courses as a pedagogical tool. this paper goes beyond previous studies [19-24], sharing an innovative experience where TED Talks are introduced as a pedagogical element that stimulates reflection and debate among sport management students. Furthermore, as a novelty, the experience is given as an approach linked to the development of the professional profile of sport management students—something demanded in previous studies in the field of sport management (e.g., [2,13]), which stresses the importance of connecting the professional world with what is taught at the university, in order to ensure that students are prepared for what the sports industry will expect of them. To this end, a total of five TED Talks of which the content enables to address the development of the professional profile of the sport management students were selected. In addition, to the best knowledge of the authors, no specific scales have been validated to assess the educational impact of TED Talks in sport management education. Thus, this work provides a new validated instrument that can be used by the entire teaching community to explore the educational impact of experiences that include TED Talks as a pedagogical element.

Although social media has been receiving more attention in educational academic literature [25], there is still a long way to go in order to explore and take advantage of the maximum educational potential offered by these tools. In part, this is due to a certain reluctance on the part of the teaching staff, who are not motivated to introduce these tools into their courses because of a feeling of lack of training, questions of privacy, technical difficulties, or a sense of loss of control over the management of 
the class $[7,10,12]$. In other cases, social media are used just superficially, as channels for sharing content without taking advantage of all the educational possibilities they offer, or are simply introduced as a trend among young people. In any case, for one reason or another, in the field of sport management education, the studies on the incorporation of social media into the university environment are still scarce [26]. For these reasons, and being aware of the fact that one of the main characteristics of social media is the interactivity that they enable, the viewing and subsequent discussion of the selected TED Talks was done through LinkedIn and YouTube, therefore being the first study that directly connects the use of TED Talks as a pedagogical resource with social media in a combined educational proposal.

In short, this paper contributes to the development of the sport management education area through two main contributions: firstly, it innovatively introduces a pedagogical resource of great interest and motivation for students into a sport management course, such as TED Talks, through YouTube and LinkedIn. Secondly, and associated with the previous point, a one-dimensional scale is developed and validated which allows the educational impact of TED Talks to be assessed when developing professional skills and competences of sport management students. The results of this study reflect part of the educational potential that YouTube, LinkedIn, and TED Talks, in combination with each other, offer. Therefore, this is becoming a valuable and accessible educational resource available to faculty, in a context where online or blended learning methodologies have recently gained prominence due to the consequences of the COVID-19 pandemic.

\section{Literature Review}

\subsection{Social Media as a Tool for Teaching, Learning and Student Professional Development}

Given the emergence and ubiquity of social media, whether intended or unintended, social media is transforming the way students communicate, collaborate and learn [10]. Thus, the academic community has increased its interest in exploring and documenting the educational potential of these tools (e.g., $[12,27,28])$. Nevertheless, although social media is perceived by educators as a powerful driver of change for teaching and learning practices, higher education teachers are still not very inclined to integrate these tools into their teaching practices for several reasons, such as cultural resistance, pedagogical issues or institutional constraints [29].

In an extensive sample-level study conducted by Manca and Ranieri [30], the authors analysed the use of social media by higher education scholars for personal, teaching and professional purposes. Among the main results, on the one hand, they found that faculty are more open to use social media for personal sharing and professional connections rather than for teaching purposes. On the other hand, they observed a positive relationship between the frequency of social media use and the development of online and/or blended methodologies.

Concerning the way that teachers introduce social media into their course dynamics, the tendency is to share and display content rather than to comment on or discuss materials or generate new ones [29]. Nevertheless, subsequent studies like the one conducted by Ansari and Khan [31] have shown how social media used from a collaborative learning approach generates a significant impact on student interactivity, both among themselves and with teachers, producing a valuable online knowledge exchange for the teaching-learning process. Other authors go further by indicating that social media enables the creation of an "authentic learning environment" of great educational potential [32]. On their part, Kumar and Nanda [33] proposed a framework to integrate social media tools into higher education institutions by addressing four major areas of concern: (1) promotion and admissions; (2) on-campus engagement; (3) alumni and networking; and (4) placement and career development. This proposal brings social media into the higher education sector by trying to maximise the potential of these tools in different educational settings as well as serving as a reference for teachers to include social media in different educational fields of action.

In terms of the type of social media included in class dynamics, social media encompasses a wide variety of platforms, with possibly the most popular being Facebook, Twitter, WhatsApp, YouTube, 
Instagram, and most recently, TikTok. In the case of sport management education literature, most studies have studied the incorporation of Twitter and Facebook [13]. Therefore, among the remaining social media types, in this work we opted to explore the possibilities of two social media which, due to their characteristics, can be easily combined for educational purposes: YouTube and LinkedIn.

On the one hand, YouTube is the most important social media for exchanging audiovisual content in the world, and the second most popular social media worldwide behind Facebook, with 2 billion active users [34]. In the educational context, YouTube is a social media that can be highly adapted as a pedagogical tool [35], enhancing the learning experience when the selected videos are relevant to the subject at hand [36]. On the other side, LinkedIn, the most relevant social media focused on the professional field, is of great importance both for companies, workers and educational institutions [29]. LinkedIn's use in a class context could stimulate employability [9] and the professional development of students [13].

Besides, the inclusion of technology and e-learning in sport management education needs to be better understood given the sporadic research found about this issue [37]. The authors also suggest the need to carry out future studies that incorporate new pedagogical perspectives that develop critical thinking and student self-employment through the introduction of new technologies and e-learning into the dynamics of the sport management lessons. Furthermore, social media have been pointed out as tools that can enhance student and faculty professional development [38,39]. Thus, given the facilities provided by YouTube for sharing audiovisual content, and LinkedIn for generating private spaces for debate, in this study, we merged both social media to introduce TED Talks as educational material for sport management students, with the aim to develop their soft skills that will be valuable for their professional future.

\subsection{TED Talks as a Pedagogical Resource in Higher Education}

The academic literature on the inclusion of TED Talks in the university context is not very prolific. Nevertheless, several studies have highlighted the potential of TED Talks in the educational field. Rubenstein [23] pointed out that TED Talks can be integrated into class lectures, discussions, and activities, both to promote student motivation and to encourage teachers to introduce innovative instructional proposals, such as the flipped classroom methodology. In addition, the author proposed a group of TED Talks that she considers could have great formative value. On the other hand, Loya and Klemm [22] highlighted TED Talks as a valuable classroom material that enhances engaging and eye-opening discussions among students and faculty. Furthermore, the authors outlined how TED Talks follow a format that is well-suited to millennial students' due to its limited duration and multimedia format that surpasses their somewhat limited attention.

On their part, Romanelli, Cain and McNamara [20] stated that teachers could use TED Talks to spark student interest and curiosity towards particular topics that are then developed with more detail within the course curriculum. Furthermore, the authors add that faculty could improve their teaching skills by watching the TED Talks and following the techniques used by the speakers. In relation to the latter, Schmidt-Crawford, Thompson and Lindstrom [40] shared an inspiring learning experience, where, during one academic year, each week, two pre-service teachers perform a "TECH Talk" which shows how to use a selected specific technology or application in teacher education. The meetings bring together undergraduate students, graduates, faculty and staff from the university, reporting very positive feedback on the experience.

Stout [24] proposed an oral presentation assignment in a Physical Chemistry course, where TED Talks were introduced with the aim to develop oral presentations skills. The result showed a positive educational impact in areas such as presentational performance, enhanced student engagement, and deeper learning. Similarity, Hayward [19] incorporated two TED Talk assignments into a public-speaking course. After watching some introductory TED Talks, the students had to do a TED Talk analysis speech through a written assignment. Furthermore, they also had to prepare and present a TED Talk to the rest of the class and to external guests. In her work, the author reflects that the results 
of these two activities are positive for the students, giving guidelines for other teachers to carry out similar learning experiences.

From another perspective, Martínez-Hernández, Vargas-Cuevas and Ramírez-Valencia [41] introduced TED Talks as a tool through which to teach English as a foreign language. The main results reflect that TED Talks generate an interest in students when learning English, by dealing with appealing current issues, learning from the speaker's movements and facial expressions, the possibility of using subtitles, as well as listening to speakers from different parts of the world with different accents.

In summary, TED Talks can be integrated into the class dynamic with a wide range of learning purposes such as: (1) generating debates and discussions about the topic content of the TED Talks; (2) viewing TED Talks to introduce or expand on topics from the course syllabus; (3) enabling students to give oral presentations imitating the TED Talks format; (4) analysing the speech and aspects of its implementation through gestures; and (5) with the idea of teaching English as a foreign language. Regardless of all these possibilities, to the best knowledge of the authors, no studies have been identified which analyse the possible impact of TED Talks on the development of the professional profile of students, nor have any specific validated scales that measure the impact that these tools may have on the sport management students been found. Therefore, and since the authors of this study believe that TED Talks have great potential when it comes to developing professional skills in sport management students, this study has the following three purposes:

1. To share an educational experience where TED lectures were introduced as a pedagogical resource through YouTube and LinkedIn in a sport management course;

2. To create and validate a new instrument to measure sport management student's perceptions towards the inclusion of the TED Talks as a pedagogical learning tool (the "TED Talks Sport Management Scale" [TED-T-SMS]);

3. To assess the effects of the educational experience carried out on students' perceptions towards the inclusion of the TED Talks as a pedagogical learning tool through a pre-test and a post-test, applying the TED-T-SMS.

\section{Methodology}

\subsection{Participants}

The sample is composed of 72 undergraduate students of Physical Activity and Sport Sciences degrees who were studying during the academic year 2018-2019 at the University of Valencia (Spain). Of the students who participated in the study, $81.90 \%$ were men, while $18.10 \%$ were women, with an average age of 22.71 (SD = 3.84). All the participants were enrolled in the "Management and Organisation of Sporting Entities and Events" course, with $93.10 \%$ of them in the third year of the degree, and $6.90 \%$ in their fourth year.

\subsection{Pedagogical Procedure}

This study is based on a quasi-experimental quantitative longitudinal design, conducted in the second semester of the 2018-2019 academic year, starting in February and concluding in May. To pursue the objectives of the study, an educational innovation was designed where initially all students had to create a LinkedIn profile and join a private LinkedIn class group created by the course professors. Before starting the innovation, the students received two introductory sessions to LinkedIn and to the TED Talks with the main aim that all students had a short period of familiarisation with the pedagogical elements involved in the innovation before it started. For instance, in these sessions, students were taught how to use LinkedIn, as well as what TED Talks are and what application they can have in sport management. One TED Talk was viewed and discussed in class as a practical example of what students would have to do later in an entirely online environment.

Within the scope of the educational intervention, a total of five TED Talks were selected in order to discuss their content with the students. To this end, the teaching staff of the course relied on a previous 
selection already made by the TED Talks platform itself, which highlights the 25 most popular talks in history on its website [42]. It is expected that these 25 talks have a fairly high level of quality as they have been the most acclaimed by users. Once this was decided, the teachers viewed the 25 talks in order to select those that offered the most significant educational possibilities to work with the students on aspects related to the development of their professional profile; for example, those that covered content such as time management, leadership or the management of communication skills. Therefore, from among these 25 talks, the following four were chosen by consensus: "How great leaders inspire action" [43], "The puzzle of motivation" [44], "How to speak so that people want to listen" [45], and "What makes a good life? Lessons from the longest study on happiness" [46]. In a second round, the TED Talk "How to gain control of your free time" [47] was chosen, despite not being among the 25 most viewed, because of the options it gave for reflecting on the skills linked to time management, which had relevance to the content of the course. Table 1 shows the five TED Talks chosen, indicating the speaker, the number of views of the talk on the official TED Talks profile on YouTube, the main topic of debate and the number of comments generated by each one on LinkedIn.

Table 1. TED Talks selected for the development of educational innovation.

\begin{tabular}{|c|c|c|c|c|}
\hline TED Talk Title & Speaker & $\begin{array}{c}\text { Number of Views } \\
\text { of the Talk on } \\
\text { YouTube * }\end{array}$ & $\begin{array}{c}\text { Main Topic } \\
\text { Linked to Sport } \\
\text { Management }\end{array}$ & $\begin{array}{l}\text { Number of } \\
\text { Comments Generated } \\
\text { in the LinkedIn TED } \\
\text { Talk Discussion Post }\end{array}$ \\
\hline $\begin{array}{l}\text { How great leaders } \\
\text { inspire action }\end{array}$ & $\begin{array}{l}\text { Simon } \\
\text { Sinek }\end{array}$ & 13.12 million & $\begin{array}{l}\text { Leadership and } \\
\text { communication }\end{array}$ & 206 \\
\hline $\begin{array}{l}\text { How to gain control of } \\
\text { your free time }\end{array}$ & $\begin{array}{c}\text { Laura } \\
\text { Vanderkam }\end{array}$ & 5.85 million & Time management & 111 \\
\hline $\begin{array}{l}\text { The puzzle of } \\
\text { motivation }\end{array}$ & Dan Pink & 9.31 million & Motivation & 138 \\
\hline $\begin{array}{l}\text { How to speak so that } \\
\text { people want to listen } \\
\text { What makes a good }\end{array}$ & $\begin{array}{l}\text { Julian } \\
\text { Treasure }\end{array}$ & 28.95 million & Communication & 100 \\
\hline $\begin{array}{l}\text { life? Lessons from the } \\
\text { longest study on } \\
\text { happiness }\end{array}$ & $\begin{array}{c}\text { Robert } \\
\text { Waldinger }\end{array}$ & 18.24 million & Happiness & 113 \\
\hline
\end{tabular}

* Note: as of 1 November 2020.

Each of the selected TED Talks was published through a post on the course's LinkedIn group with a direct link to the video of the relevant TED talk on the official TED Talks YouTube profile. In addition, the teachers posted 3-4 questions which served as a guide to open discussion about the talks. For example, in the TED Talk "How great leaders inspire action" [43], which addresses leadership and communication skills, the following questions were asked:

1. What do you think about Simon Sinek's Golden Circle theory?

2. What professional skills/abilities does the video address that are relevant to the sport manager? What applications of this TED Talk do you see for sport management?

3. Imagine that you are Carlos Velasco Carballo (president of the Technical Committee of Referees of the Royal Spanish Football Federation). Apply the theory of the Golden Circle to football's Video Assistant Referee (VAR). Define the why, the how and the what, to convince people of the importance of its use.

4. Now imagine that you were the president of a new club in your neighbourhood (specify the sport, the neighbourhood and relevant contextualisation data). Apply the golden circle theory to publicise the new club in your neighbourhood and get people to join it.

As it can be observed, the questions directly addressed specific aspects of the TED Talk (question 1), other aspects regarding the sport manager's professional skills (question 2), or required that the content 
of the TED Talk was applied to imaginary situations that are of familiarity to the students, in order to try to reflect and apply the TED Talk content in a practical context (questions 3 and 4).

The students then proceeded to answer the questions they desired, generating specific debates around each one of them. In order to leave enough time to generate a debate among the students, all of the videos were published within a timeframe of two weeks. On the other hand, the teaching staff followed the evolution of these debates by participating on several occasions, in order to stimulate discussion among the students, redirect it where necessary, as well as expand on the sub-themes dealt with in each TED Talk. All of the questions raised in the five selected TED Talks are compiled in Appendix A, in order to provide a more detailed overview of the design of the educational intervention.

Concerning aspects related to the assessment, no qualitative evaluation of the students' comments was carried out and no numerical mark was assigned to the activity. The only premise was that each student had to participate at least once in each open debate linked to the five TED Talks chosen as one of the aspects to be carried out in order to pass the course. To make it easier to check the work done, each student sent the links to each of their contributions within a document, complying with the deadline set by the teachers.

\subsection{Questionnaire Development and Testing Procedure}

Given the gap in the literature, the TED-T-SMS scale was created from the beginning. To this, several procedures were taken to achieve a validity of the content of the questionnaire. Firstly, the three authors of the research separately created an initial proposal of items focusing on obtaining the perceptions of sport management students on the use of TED Talks as a positive pedagogical tool to introduce to university classes, seeking to develop aspects linked to the professional development of students. Secondly, the authors met to share and discuss the proposed items, making a consensual selection that left an excerpt of 15 items. Thirdly, five experts analysed and screened the items, receiving feedback on the adequacy of the content to the object of study and its language clarity. The experts were selected by the authors by consensus, based on their area of knowledge and their experience of more than eight years as teachers in sport management courses. The experts proposed to merge two pairs of items because of their similarity, as well as proposing to eliminate one of them because it did not meet the objectives of the study, in addition to proposing some minor changes. Fourthly, five sport management students received the proposed 12-item scale, in order to test it and give feedback on the ease of understanding and the answerability of the items.

As a result of the whole process aforementioned, the final proposal for the TED-T-SMS was created pending its final validation process. The TED-T-SMS was developed, administered and validated in Spanish. For the present article, it was translated into English by an English native speaker who is a professional translator. In Table 2, it is possible to observe the TED-T-SMS original items in Spanish alongside their translation into English.

As for the questionnaire distributed for validation, the TED-T-SMS was formatted as a single matrix on Google Forms so that it could be answered online. The following statement headed the TED-T-SMS: “Assess the following statements on the introduction of TED Talks as a pedagogical element in sport management classes to develop the professional profile of the students. Rate each item on a scale of 1 to 5 , with 1 meaning 'I strongly disagree' and 5 meaning 'I strongly agree'”'. Therefore, a 5-point Likert scale was employed.

Prior to the first distribution of the questionnaire, students were informed about the objectives of the study, notifying them of their voluntary participation in the research, ensuring their anonymity and confidentiality in case of participation, and signing the corresponding informative consent form. On the other hand, in order to be able to measure the impact of educational innovation on students' perceptions of TED Talks as a pedagogical element in sport management classes, the questionnaire was distributed to students in two temporal moments: (1) pre-test (before starting the educational innovation); and, (2) post-test (during the week following the end of the educational innovation). All participating students were assigned a code to match the pre-test with the post-test. 
Table 2. Final version of the original TED-T-SMS in Spanish and its adaptation to English.

\begin{tabular}{|c|c|}
\hline Original TED-T-SMS & TED-T-SMS Adapted to English \\
\hline $\begin{array}{l}\text { 1. Con las TED Talks puedo inspirarme en mi } \\
\text { ámbito profesional }\end{array}$ & 1. With TED Talks I can be inspired in my professional field \\
\hline $\begin{array}{l}\text { 2. Con las TED Talks puedo motivarme en mi } \\
\text { ámbito profesional }\end{array}$ & 2. With TED Talks I can be motivated in my professional field \\
\hline 3. Escuchando TED Talks puedo divertirme & 3. By listening to TED Talks I \\
\hline $\begin{array}{l}\text { 4. Escuchando TED Talks puedo mejorar mis habilidades de } \\
\text { comunicación oral }\end{array}$ & $\begin{array}{l}\text { 4. By listening to TED Talks I can improve my oral } \\
\text { communication skills }\end{array}$ \\
\hline 5. Escuchando TED Talks puedo mejorar mi nivel de inglés & 5. By listening to TED Talks I can improve my level of English \\
\hline 6. Creo que las TED Talks favorecen & 6. I believe that TED Talks encourage entrepreneurship \\
\hline $\begin{array}{l}\text { 7. Creo que las TED Talks pueden ayudarme a mejorar } \\
\text { habilidades que son valoradas positivamente por los } \\
\text { empleadores }\end{array}$ & $\begin{array}{l}\text { 7. I believe that TED Talks can help me improve skills that are } \\
\text { valued positively by employers }\end{array}$ \\
\hline $\begin{array}{l}\text { 8. Creo que escuchar TED Talks pueden influir positivamente } \\
\text { en mi futuro profesional }\end{array}$ & $\begin{array}{l}\text { 8. I believe that listening to TED Talks can have a positive } \\
\text { influence on my professional future }\end{array}$ \\
\hline $\begin{array}{l}\text { 9. Creo que las TED Talks son una buena herramienta de } \\
\text { aprendizaje de cara a introducir en las clases de universidad }\end{array}$ & $\begin{array}{l}\text { 9. I think that TED Talks are a good learning tool to introduce } \\
\text { to university classes }\end{array}$ \\
\hline $\begin{array}{l}\text { 10. Creo que a través de las TED Talks puedo aprender cosas } \\
\text { que normalmente no se enseñan en las clases de la universidad }\end{array}$ & $\begin{array}{l}\text { 10. I believe that through TED Talks I can learn things that are } \\
\text { not normally taught in university classes }\end{array}$ \\
\hline $\begin{array}{l}\text { 11. Las TED Talks son una buena opción para aprender sobre } \\
\text { aspectos vinculados con la gestión del deporte }\end{array}$ & $\begin{array}{l}\text { 11. TED Talks are a good option to learn about aspects related } \\
\text { to sport management }\end{array}$ \\
\hline $\begin{array}{l}\text { 12. Recomendaría a los gestores del deporte que visionasen } \\
\text { TED Talks }\end{array}$ & 12. I would recommend sports managers to view TED Talks \\
\hline
\end{tabular}

\subsection{Statistical Analysis}

An Exploratory Factor Analysis (EFA) was performed to evaluate the validity of this scale. Due to the fact that the EFA shows that this scale was composed by only one dimension, it was not necessary to perform the confirmatory factor analysis (CFA). The indicators related to sampling adequacy measure were analysed. These indicators present if this model analysis is appropriate for the data [48]. Once that condition had been verified, the degree of joint relationship between the items were evaluated. The most common measure is Kaiser's [49] KMO (Kaiser-Meyer Olkin) test, that evaluates to what extent the scores in each of the items are predictable from the others. The range of KMO values is from 0 to 1 , and the higher the value, the more relationship there is between items. Kaiser [49] suggested that $\mathrm{KMO}$ equal to or greater than 0.80 ensures that the correlation matrix is appropriate.

Next, the EFA was performed for the extraction of the main components using a Varimax rotation (orthogonal rotation). The main advantage of this technique is its simplicity, as the weights represent the correlations between the factors and variables. It was proposed by Kaiser [50], and it attempts to show that the factors have few high saturations, and many almost null in the variables. The criteria to eliminate items were factorial loads lower than 0.40 , as well as those with loads higher than 0.40 in several constructs. However, in his case, it was not necessary to delete any of them. After that, the reliability of the scale was evaluated using Cronbach's alpha. Cronbach and Shavelson [51], for internal consistency, considered that Cronbach's alpha of 60 are low, $\geq 0.60$ are adequate and values $\geq 0.70$ are high.

Finally, the means of the post-test and pre-test were compared to evaluate the effects of the educational innovation. A test for intragroups comparisons for non-normal sample was used; due to the size sample, the normality of the data was not proved. Hence, the Wilcoxon test was used to compare the pre-test and post-test means. Finally, de Cohen's $d$ was calculated to evaluate the effect size of the differences. Values below 0.20 were considered small, values between 0.20 and 0.80 were considered medium, while values above 0.80 were considered large [52]. The data analysed were performed using the statistical package SPSS (Version 23, IBM Corp, Armonk, NY, USA) and effect size calculator. 


\section{Results}

In this section, first of all, the results related to the validity of the scale and reliability of the created scale are presented. Hereafter, the intragroup means that comparisons between the pre-test and the post-test are displayed.

\subsection{Exploratory Factor Analysis}

Firstly, descriptive statistics were calculated for the different items that compose the scale. As can be seen in Table 3, the item with the highest average was "With TED Talks I can be motivated in my professional field" with an average of $4.13(\mathrm{D}=0.77)$. At the other end, the item with the lowest average $(\mathrm{M}=3.81$; $\mathrm{SD}=0.80)$ was "TED Talks are a good option to learn about aspects related to sport management".

As far as exploratory factor analysis is concerned, to study the validity of the construct, a principal component analysis with Varimax rotation was performed. The KMO value was $0.912(p<0.05)$, confirming the measure of sampling adequacy, and Bartlett's test of sphericity value was 714.903, $\mathrm{df}=66(p<0.001)$, providing evidence for a significant correlation among the items. One dimension was obtained explaining the $64.36 \%$ of the variance, as can be observed in Table 3 . Then, the factorial loads of all items were evaluated. All of the items had factorial loads above 0.40 , so in this first step it was not necessary to eliminate any of them, leaving this scale composed of 12 items.

Table 3. Means, Statistical Deviation, factorial loads of the items of the factor extracted, and explained variance of each factor.

\begin{tabular}{|c|c|c|c|c|}
\hline & Items & $\mathbf{M}$ & SD & Factorial Loads \\
\hline 1 & With TED Talks I can be inspired in my professional field & 4.07 & 0.78 & 0.873 \\
\hline 2 & With TED Talks I can be motivated in my professional field & 4.13 & 0.77 & 0.836 \\
\hline 3 & By listening to TED Talks I can have fun & 3.92 & 0.80 & 0.692 \\
\hline 4 & $\begin{array}{l}\text { By listening to TED Talks I can improve my oral } \\
\text { communication skills }\end{array}$ & 4.00 & 0.77 & 0.773 \\
\hline 5 & By listening to TED Talks I can improve my level of English & 3.86 & 0.84 & 0.514 \\
\hline 6 & I believe that TED Talks encourage entrepreneurship & 3.96 & 0.74 & 0.789 \\
\hline 7 & $\begin{array}{l}\text { I believe that TED Talks can help me improve skills that are } \\
\text { valued positively by employers }\end{array}$ & 4.03 & 0.77 & 0.848 \\
\hline 8 & $\begin{array}{l}\text { I believe that listening to TED Talks can have a positive } \\
\text { influence on my professional future }\end{array}$ & 3.99 & 0.76 & 0.825 \\
\hline 9 & $\begin{array}{l}\text { I think that TED Talks are a good learning tool to introduce } \\
\text { to university classes }\end{array}$ & 3.93 & 0.76 & 0.853 \\
\hline 10 & $\begin{array}{l}\text { I believe that through TED Talks I can learn things that are } \\
\text { not normally taught in university classes }\end{array}$ & 4.03 & 0.86 & 0.831 \\
\hline 11 & $\begin{array}{l}\text { TED Talks are a good option to learn about aspects related to } \\
\text { sport management }\end{array}$ & 3.81 & 0.80 & 0.751 \\
\hline 12 & I would recommend sports managers to view TED Talks & 3.85 & 0.80 & 0.865 \\
\hline & Eigenvalue & \multicolumn{3}{|c|}{$\begin{array}{c}7.72 \\
64.36 \%\end{array}$} \\
\hline & Total variance explained & \multicolumn{3}{|c|}{$64.36 \%$} \\
\hline
\end{tabular}

\subsection{Reliability}

Table 4 below shows the correlations between items, and whether Cronbach's alpha increases if any item is removed. As can be observed, all items have correlations above 0.60 between them. Furthermore, if any of the items are eliminated, Cronbach's alpha does not increase (see Table 4). Therefore, without the necessity to eliminate any item, Cronbach's alpha on this scale was 0.95. 
Table 4. Factorial loads of the items in each factor extracted, explained variance and reliability of each factor.

\begin{tabular}{llcc}
\hline & \multicolumn{1}{c}{ Items } & rjx & $\alpha-\mathbf{x}$ \\
\hline 1 & With TED Talks I can be inspired in my professional field & 0.84 & 0.94 \\
2 & With TED Talks I can be motivated in my professional field & 0.81 & 0.94 \\
3 & By listening to TED Talks I can have fun & 0.66 & 0.95 \\
4 & By listening to TED Talks I can improve my oral communication skills & 0.73 & 0.94 \\
5 & By listening to TED Talks I can improve my level of English & 0.45 & 0.95 \\
6 & I believe that TED Talks encourage entrepreneurship & 0.76 & 0.94 \\
7 & I believe that TED Talks can help me improve skills that are valued positively by & 0.82 & 0.94 \\
8 & Ibelievers that listening to TED Talks can have a positive influence on my professional future & 0.81 & 0.94 \\
9 & I think that TED Talks are a good learning tool to introduce to university classes & 0.86 & 0.94 \\
10 & I believe that through TED Talks I can learn things that are not normally taught in & 0.80 & 0.94 \\
11 & university classes & 0.69 & 0.94 \\
12 & TED Talks are a good option to learn about aspects related to sport management & 0.82 & 0.94 \\
\hline
\end{tabular}

\subsection{Means Comparisons: Post-Test versus Pre-Test}

Concerning the pre-test and post-test means comparisons, as can be observed in Table 5, the post-test means were higher than the pre-test means for all items. However, these differences were only statistically significant for six of these items. Specifically, in the item "By listening to TED Talks I can improve my level of English" the pre-test mean was $3.86(\mathrm{SD}=0.84)$ while the post-test mean was $4.13(\mathrm{SD}=0.82 ; p<0.05)$. Furthermore, these differences were also statistically significant in the item "I believe that TED Talks encourage entrepreneurship". The students presented a significantly higher means $(p<0.05)$ in the post-test $(4.19 ; \mathrm{SD}=0.71)$ compared to the pre-test $(3.96 ; \mathrm{SD}=0.74)$. The effect size in both cases was medium (Cohen's $d=0.33$; Cohen's $d=0.32$, respectively).

Table 5. Comparison of pre-test and post-test means of sports management university students.

\begin{tabular}{|c|c|c|c|c|c|c|}
\hline & Items & $\begin{array}{l}\text { Pre-Test } \\
\text { (M; SD) }\end{array}$ & $\begin{array}{l}\text { Post-Test } \\
\text { (M; SD) }\end{array}$ & $Z$ & $p$ & Cohen's $d$ \\
\hline 1 & $\begin{array}{l}\text { With TED Talks I can be inspired in my } \\
\text { professional field }\end{array}$ & $4.07(0.78)$ & $4.21(0.79)$ & -1.48 & 0.139 & - \\
\hline 2 & $\begin{array}{l}\text { With TED Talks I can be motivated in my } \\
\text { professional field }\end{array}$ & $4.13(0.77)$ & $4.24(0.72)$ & -1.21 & 0.226 & - \\
\hline 3 & By listening to TED Talks I can have fun & $3.92(0.80)$ & $4.13(0.79)$ & -1.83 & 0.067 & - \\
\hline 4 & $\begin{array}{l}\text { By listening to TED Talks I can improve my oral } \\
\text { communication skills }\end{array}$ & $4.00(0.77)$ & $4.21(0.73)$ & -1.79 & 0.074 & - \\
\hline 5 & $\begin{array}{l}\text { By listening to TED Talks I can improve my level } \\
\text { of English }\end{array}$ & $3.86(0.84)$ & $4.13(0.82)$ & -2.14 & 0.032 & 0.33 \\
\hline 6 & $\begin{array}{l}\text { I believe that TED Talks encourage } \\
\text { entrepreneurship }\end{array}$ & $3.96(0.74)$ & $4.19(0.71)$ & -2.23 & 0.026 & 0.32 \\
\hline 7 & $\begin{array}{l}\text { I believe that TED Talks can help me improve } \\
\text { skills that are valued positively by employers }\end{array}$ & $4.03(0.77)$ & $4.19(0.66)$ & -1.52 & 0.129 & - \\
\hline 8 & $\begin{array}{l}\text { I believe that listening to TED Talks can have a } \\
\text { positive influence on my professional future }\end{array}$ & $3.99(0.76)$ & $4.12(0.79)$ & -1.17 & 0.243 & - \\
\hline 9 & $\begin{array}{l}\text { I think that TED Talks are a good learning tool to } \\
\text { introduce to university classes }\end{array}$ & $3.93(0.76)$ & $4.24(0.70)$ & -2.48 & 0.013 & 0.42 \\
\hline 10 & $\begin{array}{l}\text { I believe that through TED Talks I can learn things } \\
\text { that are not normally taught in university classes }\end{array}$ & $4.03(0.86)$ & $4.31(0.71)$ & -2.30 & 0.021 & 0.36 \\
\hline 11 & $\begin{array}{l}\text { TED Talks are a good option to learn about } \\
\text { aspects related to sport management }\end{array}$ & $3.81(0.79)$ & $4.10(0.77)$ & -2.28 & 0.023 & 0.37 \\
\hline 12 & $\begin{array}{l}\text { I would recommend sports managers to view } \\
\text { TED Talks }\end{array}$ & $3.85(0.80)$ & $4.29(0.81)$ & -3.38 & 0.001 & 0.55 \\
\hline
\end{tabular}

On the other hand, in the items most related to TED Talks as a university learning tool, "I think that TED Talks are a good learning tool to introduce to university classes" and "I believe that through 
TED Talks I can learn things that are not normally taught in university classes", students also presented significantly higher averages $(p<0.05)$ in the post-test $(\mathrm{M}=4.24, \mathrm{SD}=0.70 ; \mathrm{M}=4.31, \mathrm{SD}=0.71$, respectively) compared to the pre-test $(\mathrm{M}=3.93, \mathrm{SD}=0.76 ; \mathrm{M}=4.03, \mathrm{SD}=0.86)$. The effect size was also medium in both cases (Cohen's $d=0.42$; Cohen's $d=0.36$, respectively).

Finally, statistically significant differences were also found in the items related to TED Talks as a useful tool for sport management. Specifically, these items were "TED Talks are a good option to learn about aspects related to sport management" and "I would recommend sports managers to view TED Talks", with students presenting a significantly higher average in both cases $(p=<0.05$ and $p=<0.001$, respectively), in the post-test ( $\mathrm{M}=4.10, \mathrm{SD}=0.77 ; \mathrm{M}=4.29, \mathrm{SD}=0.81$, respectively), with respect to the pre-test $(\mathrm{M}=3.81, \mathrm{SD}=0.79 ; \mathrm{M}=3.85, \mathrm{SD}=0.80)$. The effect size was also medium in both cases (Cohen's d $=0.37$; Cohen's d $=0.55$, respectively). These results can be observed in Table 5 .

Lastly, as regards the perception of how much students believe they can learn from TED Talks on sport management and professional development issues, it can be observed from Table 6 that there are statistically significant differences $(p=0.005)$ between the pre-test and the post-test means. Specifically, the pre-test mean was $7.58(\mathrm{SD}=1.50)$, therefore lower than the post-test mean of $8.21(\mathrm{SD}=1.51)$. The effect size was medium (Cohen's $d=0.42$ ).

Table 6. Comparison of pre-test and post-test means of general perception of TED Talks as a tool for learning sport management aspects.

\begin{tabular}{cccccc}
\hline \multicolumn{1}{c}{ Items } & $\begin{array}{c}\text { Pre-Test } \\
(\mathbf{M} \text { SD) }\end{array}$ & $\begin{array}{c}\text { Post-Test } \\
\text { (M; SD) }\end{array}$ & Z & $p$ & Cohen's $d$ \\
\hline $\begin{array}{l}\text { Rate from 1 to 10 how much you think you can learn } \\
\text { with TED Talks about aspects of sport management } \\
\text { and your professional development }\end{array}$ & $7.58(1.50)$ & $8.21(1.51)$ & -2.80 & 0.005 & 0.42 \\
\hline
\end{tabular}

\section{Discussion}

Academic research has increased the focus on online teaching methodologies in light of the changes that the COVID-19 pandemic has had on the education system. In that sense, social media can become a valuable element in creating online learning environments. On the other hand, teachers are also increasingly looking for diverse material, such as TED Talks, that can be easily incorporated into online or blended learning educational methodologies. However, both the current literature on the educational impact of social media and the pedagogical possibilities of TED Talks are scarce, especially in the field of sport management education. Furthermore, there is a lack of validated instruments to assess the impact of educational experiences that encourage the incorporation of social media and TED Talks into the classroom. This paper aims to cover those research gaps, through an educational experience where TED Talks are introduced as a pedagogical element through YouTube and LinkedIn for third-year undergraduate students of a sport management course.

Concerning the first objective of the study, the results of the students' perceptions regarding the experience at a global level are very positive, with this perception increasing significantly after the educational experience. This reflects the potential that TED Talks have when introduced in sport management classes, thinking about the professional development of students, thus educating them in a relevant scope for their training as reflected in various studies $[9,13]$. Besides, the results of the educational experience reflect the favourable tandem formed by YouTube and LinkedIn in the educational field, reflecting the need for studies that go deeper into the pedagogical possibilities of social media that go beyond Facebook and Twitter [12,13]. We would like to emphasise this aspect, given that the introduction of TED Talks through social media is a step further compared to how previous studies linked to TED Talks [19-24] have introduced this pedagogical resource into course dynamics. Furthermore, what is noteworthy is the potential for the use of social media for educational purposes in a COVID-19 pandemic context, where online learning is on the rise. Hence, the proposal made on this work can guide future applications of TED Talks in the university context. 
In the case of YouTube, this tool facilitates the dissemination of videos selected by teachers and/or students that are relevant to the course [36]. As far as LinkedIn is concerned, it allows for the creation of private educational spaces where the class can reflect on and debate the video content in a controlled environment that is attractive to students [13]. Furthermore, it is also worth highlighting the significant amount of interactivity, both student-student and student-faculty, that these two social media have facilitated in combination. This interactivity, as stressed by Colomer et al. [53], is an important factor in determining student learning experiences, which was also enhanced by the initial questions set out in each TED Talk post, with the aim of stimulating critical thinking among students. In this educational experience, more than 600 comments among the five discussion threads were generated, thus confirming what has been stated by authors such as Ansari and Khan [31], who highlighted this interactive learning that generates an exchange of knowledge between all the participants in the educational experience, creating these open discussions that engage the students, as Loya and Klemm [22] point out. In the same sense, Stout [24] also highlighted the influence of using TED Talks as a pedagogical tool towards student engagement. This is confirmed by our experience, despite the fact that in our case the students did not perform oral presentations imitating the TED lectures. For all the reasons mentioned above, we agree with Rubenstein [23] in relation to the potential of TED Talks to inspire thoughtful learning that provides relevant and meaningful learning (in our case focused on professional development) to the students, in an educational environment that is in constant evolution. This study can guide the teaching community towards the future inclusion of TED Talks, YouTube and LinkedIn, jointly, both in sport management classes and in others educational contexts.

Regarding the second objective of the study, this research developed the TED-T-SMS, composed of a single 12-item dimension, which allows for the assessment of students' perceptions of the educational potential of TED lectures in the context of sport management, from a perspective of the development of the students' professional profile. The results reveal an instrument that it is valid for measuring these perceptions, explaining a large percentage of the variance. Therefore, this study offers the teaching community a new tool that will allow a better evaluation of the educational impact of the learning experiences based on the introduction of TED Talks as a pedagogical resource. Thus, this allows teachers to determine which experiences have a greater or lesser impact on student learning. Consequently, we determine that TED-T-SMS is a worthwhile instrument since it covers a gap in the literature regarding validated instruments about the researched topic. However, TED-T-SMS should be used and examined in future studies, to corroborate its validity.

While focusing on the items that presented significant differences, this study, like the one conducted by Martínez-Hernández, Vargas-Cuevas and Ramírez-Valencia [41], has shown a positive impact towards the improvement of English language skills. This is especially interesting in the Spanish context, where the majority of students do not reach the B2 level of the Common European Framework of Reference for Languages (CEFR). By working on English language skills transversally, through TED Talks, both at a listening level and with subtitles, the students can improve their level of English. This is something that would be of great value for their professional future, since this language is increasingly necessary for the labour market.

On the other hand, the significant increase in the number of aspects linked to entrepreneurship reflects the inspirational and motivational value of the TED Talks highlighted in the study by Romanelli, Cain and McNamara [20]. In addition, the results have also shown the ability of TED Talks to work across subject areas. This can be of great value to teachers when it comes to introducing more dynamic and innovative methodologies, as Robenstein [23] pointed out, which break with the traditional learning model where the teacher carries the weight of the teaching-learning process. To this, we must add that students have seen the TED Talks as an element that they perceive should be included in university classes, through which they learn things that are not normally taught at university. In this sense, TED Talks, as Loya and Klemn [22] noted, enrich the teaching opportunities remaining limited to the imagination of the teaching faculty. Last but not least, we also underline the link that the students establish between the TED Talks and the professional world, which is the one that presents 
the highest level of significance, perceiving that the TED Talks are a resource that they would advise sport managers to look at. In this sense, it would be good to carry out some qualitative study that explores in greater depth the reasons behind this perception.

\section{Limitations and Future Research Lines}

This study is not exempt from limitations. On the one hand, the sample is not very large, being limited to the students who participated in the educational experience and also completed both the pre-test and the post-test voluntarily. Furthermore, no control group has been used, so it cannot be guaranteed that the impact of the educational intervention is due to the intervention itself, or to other uncontrolled interventions or factors. In addition, in the case of the results of the pre-test, it should be stressed that the results obtained should be interpreted as expectations and/or beliefs, as the students had not yet experienced the proposed TED Talks proposal when they completed the TED-T-SMS for the first time. On the other hand, this educational experience included five TED Talks among the large number available. In addition, a series of specific questions were chosen (see Appendix A) to make the debates more interactive. These decisions exclude a wide variety of options when introducing TED Talks into university classes. A further limiting element has been the lack of similar studies in higher education academic literature and in particular in sport management education. Therefore, the discussion in this study has been limited, focusing on an interpretation of the results by the authors. For these reasons, the results should be taken with caution without making generalisations. As for the validation of TED-T-SMS, this is also limited by the sample size, even though the analyses carried out show good psychometric properties. The study is also limited by the measurement element itself, as it is quantitative, leaving aside the use of qualitative methods that would have complemented the results obtained through TED-T-SMS.

Derived from the limitations indicated above, the following future lines of research are proposed. Firstly, it is recommended to put into action similar experiences to the one shared in this work, with larger samples and with a control group, where TED Talks are used from a pedagogical perspective in sport management classes. In this sense, it would also be advisable to carry out studies in other educational contexts (e.g., North American, Asian, and so on), where there are differences in the sport management education and the culture concerning the professional development of the students, in order to carry out comparative studies. Secondly, it would be interesting to conduct a similar study using TED-T-SMS to measure TED Talks educational impact, but changing the selection of TED Talks and/or questions to stimulate the debates, in order to assess whether or not the results coincide with those obtained in this study. Thirdly, it is necessary to test the validity of TED-T-SMS in larger samples, in order to confirm its properties and to give more flexibility and robustness to the scale. Furthermore, future studies can explore the incorporation of new items that lead to possible new dimensions, enriching the predictive potential of the scale. In addition, it is also suggested to include qualitative methods to obtain the data in future studies, such as interviews or focus groups, in order to be able to interpret the impact of the inclusion of TED Talks on sport management classes from a complementary perspective to the quantitative one. Finally, the scale could be adapted to English, or other languages, as well as the validation process, in order to ensure that TED-T-SMS is a useful tool for the whole teaching and research community.

\section{Conclusions}

This study provides an advance in both the practical and theoretical levels of sport management education. On the one hand, it proposes and measures the impact of an educational experience where TED Talks are introduced, through YouTube and LinkedIn, as a pedagogical element in the classes of sport management to develop the professional profile of the students and the curriculum of the course. In this way, the study shares an educational proposal to develop the student's professional skills and competencies in class that will be relevant for their professional future, therefore connecting part of the 
demands of the sports industry with what is taught in class. In that way, the employability of these students could be enhanced.

On the other hand, the validation of TED-T-SMS has shown good psychometric properties. This is a valuable development since the literature does not cover validated instruments for the concrete assessment of the educational potential of TED Talks in relation to the development of professional skills. In this sense, this instrument gives visibility to students' perceptions in an area of education that is increasingly relevant, given the greater competitiveness of the labour market. Therefore, this study provides a useful instrument for both teachers and researchers who wish to know in a scientific way the impact of their educational experiences.

Given the transversality and diversity of the content of TED Talks, the shared experience can also be useful to the whole teaching community as a starting point for future similar experiences in other areas of knowledge (e.g., communication, psychology, political sciences, business or teacher training). Furthermore, the paper is also innovative, offering a proposal on how to introduce social media in a combined way in university classes, creating an excellent online learning environment for pedagogical purposes. This is important given the effects of the COVID-19 pandemic, which has led to online learning-based methods. In this sense, this study shows how social media can be a solution to help preserve sustainability in higher education, in a context where universities are experiencing periods of lockdowns.

In conclusion and as a synthesis, given the positive educational impact of TED Talks and the usefulness of YouTube and LinkedIn in combination with each other when generating a learning environment as well as the psychometric properties of the scale developed, it is recommended that the sports management teaching community carries out similar experiences, using TED-T-SMS to measure their impact.

Author Contributions: Conceptualization, S.L.-C. and V.A.; methodology, S.L.-C. and M.H.G.-S.; validation, M.H.G.-S.; formal analysis, M.H.G.-S.; investigation, S.L.-C.; resources, S.L.-C.; data curation, M.H.G.-S.; writing-original draft preparation, S.L.-C. and M.H.G.-S.; writing-review and editing, S.L.-C. and V.A.; supervision, V.A.; project administration, S.L.-C.; funding acquisition, S.L.-C. All authors have read and agreed to the published version of the manuscript.

Funding: This work was supported within the project: "Development of digital skills in sport management through the introduction of social media LinkedIn and YouTube" selected within the Teaching Methodology Renewal Programme, in the University of Valencia's call for Educational Innovation Projects for the 2018/19 academic year.

Acknowledgments: We would like to express our gratitude to all the experts who voluntarily participated in the process of creating and refining the validated scale, besides the students who participated in the study. On the other hand, the first author of this work is grateful for the support of a predoctoral contract "FPU15/05670" granted by the Spanish Ministry of Science, Innovation and Universities.

Conflicts of Interest: The authors declare no conflict of interest.

\section{Appendix A}

Questions and proposals for activities to be carried out by students linked to each of the TED Talks used in this study as pedagogical material.

TED Talk: "How great leaders inspire action" [43]

1. What do you think about Simon Sinek's Golden Circle theory?

2. What professional skills/abilities does the video address that are relevant to the sport manager? What applications of this TED Talk do you see for sport management?

3. Imagine that you are Carlos Velasco Carballo (president of the Technical Committee of Referees of the Royal Spanish Football Federation). Apply the theory of the Golden Circle to football's Video Assistant Referee (VAR). Define the why, the how and the what, to convince people of the importance of its use. 
4. Now imagine that you were the president of a new club in your neighbourhood (specify the sport, the neighbourhood and relevant contextualisation data). Apply the golden circle theory to publicise the new club in your neighbourhood and get people to join it.

TED Talk: "How to gain control of your free time" [47]

1. What are the key points that Laura Vanderkam proposes to time management?

2. How do you manage your time? What are your criteria? Are you happy with your time management?

3. Do you use any organisational tools or strategies to manage your time? (share it with the class).

TED Talk: “The puzzle of motivation" [44]

1. Where is the mismatch between what science says about managing intrinsic and extrinsic motivation and what most companies do in practice?

2. As university students, do you think that the degree courses operate in a similar way to most companies?

3. How would you transfer the concepts of autonomy, mastery and purpose that Dan Pink talks about to the world of sports management?

TED Talk: "How to speak so that people want to listen" [45]

1. In your daily life, do you listen to people? Which of the seven sins pointed out by Julian Treasure do you normally commit?

2. What do you think about the suggestions Julian Treasure gives to improve your ability to communicate?

3. Do you think communication is important in the world of sports management? Why?

TED Talk: "What makes a good life? Lessons from the longest study on happiness" [46]

1. What did you think about the research presented by Robert Waldinger?

2. After listening to the TED talk, how do you think about what's left of your life?

3. How would you link the results of this study on the management of relationships in sport management context? What opportunities do we have?

4. What is the role of happiness in management?

\section{References}

1. Nadelson, L.S.; Berg, W.; Fox, B.; Grandbouche, P.; Harris, M.; Kroschel, T.L.; Sandoval, S. Snap, Tweet and Post: College Student Social Media Perceptions and Heutagogic Practices and Uses. Int. J. High. Educ. 2017, 6, 11. [CrossRef]

2. Osgerby, J.; Rush, D. An exploratory case study examining undergraduate accounting students' perceptions of using Twitter as a learning support tool. Int. J. Manag. Educ. 2015, 13, 337-348. [CrossRef]

3. López-Carril, S.; Villamón, M.; Añó, V. Conceptualización de los medios sociales: Oportunidades para la gestión del deporte. Retos 2019, 36, 578-583. [CrossRef]

4. Zailskaitè-Jakštè, L.; Kuvykaite, R. Implementation of Communication in Social Media by Promoting Studies at Higher Education Institutions. Eng. Econ. 2012, 23, 174-188. [CrossRef]

5. Alalwan, A.A.; Rana, N.P.; Dwivedi, Y.K.; Algharabat, R. Social media in marketing: A review and analysis of the existing literature. Telemat. Inform. 2017, 34, 1177-1190. [CrossRef]

6. Odunaiya, O.; Agoyi, M.; Osemeahon, O.S. Social TV Engagement for Increasing and Sustaining Social TV Viewers. Sustainability 2020, 12, 4906. [CrossRef]

7. Zachos, G.; Paraskevopoulou-Kollia, E.-A.; Anagnostopoulos, I. Social Media Use in Higher Education: A Review. Educ. Sci. 2018, 8, 194. [CrossRef] 
8. Malik, A.; Heyman-Schrum, C.; Johri, A. Use of Twitter across educational settings: A review of the literature. Int. J. Educ. Technol. High. Educ. 2019, 16, 1-22. [CrossRef]

9. Stathopoulou, A.; Siamagka, N.-T.; Christodoulides, G. A multi-stakeholder view of social media as a supporting tool in higher education: An educator-student perspective. Eur. Manag. J. 2019, 37, 421-431. [CrossRef]

10. Tess, P.A. The role of social media in higher education classes (real and virtual) - A literature review. Comput. Hum. Behav. 2013, 29, A60-A68. [CrossRef]

11. Voorn, R.J.J.; Kommers, P.A.M. Social media and higher education: Introversion and collaborative learning from the student's perspective. Int. J. Soc. Media Interact. Learn. Environ. 2013, 1, 59. [CrossRef]

12. Manca, S. Snapping, pinning, liking or texting: Investigating social media in higher education beyond Facebook. Internet High. Educ. 2020, 44, 100707. [CrossRef]

13. López-Carril, S.; Anagnostopoulos, C.; Parganas, P. Social media in sport management education: Introducing LinkedIn. J. Hosp. Leis. Sport Tour. Educ. 2020, 27, 100262. [CrossRef] [PubMed]

14. Murphy, M.P.A. COVID-19 and emergency eLearning: Consequences of the securitization of higher education for post-pandemic pedagogy. Contemp. Secur. Policy 2020, 41, 492-505. [CrossRef]

15. Carrillo, C.; Flores, M.A. COVID-19 and teacher education: A literature review of online teaching and learning practices. Eur. J. Teach. Educ. 2020, 43, 466-487. [CrossRef]

16. Sobaih, A.E.E.; Hasanein, A.M.; Abu Elnasr, A.E. Responses to COVID-19 in Higher Education: Social Media Usage for Sustaining Formal Academic Communication in Developing Countries. Sustainability 2020, 12, 6520. [CrossRef]

17. Karataş, T.Ö.; Tuncer, H. Sustaining Language Skills Development of Pre-Service EFL Teachers despite the COVID-19 Interruption: A Case of Emergency Distance Education. Sustainability 2020, 12, 8188. [CrossRef]

18. Williamson, B.; Eynon, R.; Potter, J. Pandemic politics, pedagogies and practices: Digital technologies and distance education during the coronavirus emergency. Learn. Media Technol. 2020, 45, 107-114. [CrossRef]

19. Hayward, P.A. Incorporating TED Talk assignments into a public-speaking course. Commun. Teach. 2017, 31, 239-244. [CrossRef]

20. Romanelli, F.; Cain, J.; McNamara, P.J. Should TED Talks Be Teaching Us Something? Am. J. Pharm. Educ. 2014, 78, 113. [CrossRef]

21. Sugimoto, C.R.; Thelwall, M.; Larivière, V.; Tsou, A.; Mongeon, P.; Macaluso, B. Scientists Popularizing Science: Characteristics and Impact of TED Talk Presenters. PLoS ONE 2013, 8, e62403. [CrossRef] [PubMed]

22. Loya, M.A.; Klemm, T. Teaching note-Using TED Talks in the social work classroom: Encouraging student engagement and discourse. J. Soc. Work. Educ. 2016, 52, 518-523. [CrossRef]

23. Rubenstein, L.D. Using TED Talks to Inspire Thoughtful Practice. Teach. Educ. 2012, 47, 261-267. [CrossRef]

24. Stout, R.P. Reimagining an Oral Presentation Assignment as a TED Talk Improves Student Oral Presentations, Leading to More Significant Learning. J. Chem. Educ. 2019, 97, 271-274. [CrossRef]

25. Almulla, M. Social media use for educational purposes: Systematic Literature Review in higher education of Middle East Countries (MEC). Int. J. Adv. Trends Comput. Sci. Eng. 2020, 9, 1935-1944. [CrossRef]

26. Lopez-Carril, S.; Escamilla-Fajardo, P.; Gonzalez-Serrano, M.H.; Ratten, V.; Gonzalez-Garcia, R.J. The Rise of Social Media in Sport: A Bibliometric Analysis. Int. J. Innov. Technol. Manag. 2020, 17, 2050041. [CrossRef]

27. Abdulqader, M.M.; Almunsour, Y.Z. Investigating the Effects of Social Media on Higher Education with a Case Study. J. Inf. Knowl. Manag. 2020, 19, 2040023. [CrossRef]

28. Greenhow, C.; Galvin, S. Teaching with social media: Evidence-based strategies for making remote higher education less remote. Inf. Learn. Sci. 2020, 121, 513-524. [CrossRef]

29. Manca, S.; Ranieri, M. Facebook and the Others. Potentials and obstacles of Social Media for teaching in higher education. Comput. Educ. 2016, 95, 216-230. [CrossRef]

30. Manca, S.; Ranieri, M. "Yes for sharing, no for teaching!": Social Media in academic practices. Internet High. Educ. 2016, 29, 63-74. [CrossRef]

31. Ansari, J.A.N.; Khan, N.A. Exploring the role of social media in collaborative learning the new domain of learning. Smart Learn. Environ. 2020, 7, 1-16. [CrossRef]

32. Mulyono, H.; Suryoputro, G. The use of social media platform to promote authentic learning environment in higher education setting. Sci. Educ. Today 2020, 10, 105-123. [CrossRef]

33. Kumar, V.; Nanda, P. Social Media in Higher Education: A Framework for Continuous Engagement. Int. J. Inf. Commun. Technol. Educ. 2018, 15, 109-120. [CrossRef] 
34. Most Popular Social Networks Worldwide as of July 2020, Ranked by Number of Active Users. Available online: https://www.statista.com/statistics/272014/global-social-networks-ranked-by-number-of-users/ (accessed on 4 November 2020).

35. Szeto, E.; Cheng, A.Y.-N.; Hong, J.-C. Learning with Social Media: How Do Preservice Teachers Integrate YouTube and Social Media in Teaching? Asia-Pacific Educ. Res. 2015, 25, 35-44. [CrossRef]

36. Moghavvemi, S.; Sulaiman, A.; Jaafar, N.I.; Kasem, N. Social media as a complementary learning tool for teaching and learning: The case of youtube. Int. J. Manag. Educ. 2018, 16, 37-42. [CrossRef]

37. Miragaia, D.A.; Soares, J.A. Higher education in sport management: A systematic review of research topics and trends. J. Hosp. Leis. Sport Tour. Educ. 2017, 21, 101-116. [CrossRef]

38. Harvey, S.; Carpenter, J.P.; Hyndman, B.P. Introduction to Social Media for Professional Development and Learning in Physical Education and Sport Pedagogy. J. Teach. Phys. Educ. 2020, 39, 1-9. [CrossRef]

39. Luo, T.; Freeman, C.; Stefaniak, J. "Like, comment, and share"—Professional development through social media in higher education: A systematic review. Educ. Technol. Res. Dev. 2020, 68, 1659-1683. [CrossRef]

40. Schmidt-Crawford, D.; Thompson, A.D.; Lindstrom, D. TECH Talks: Inspiring Informal Learning. J. Digit. Learn. Teach. Educ. 2016, 32, 83-84. [CrossRef]

41. Martínez-Hernández, M.A.; Vargas-Cuevas, J.A.; Ramírez-Valencia, A. TED Talks as an ICT Tool to Promote Communicative Skills in EFL Students. Engl. Lang. Teach. 2018, 11, 106-115. [CrossRef]

42. The Most Popular TED Talks of All Time. Available online: https://www.ted.com/playlists/171/the_most_ popular_talks_of_all (accessed on 30 October 2020).

43. How Great Leaders Inspire Action|Simon Sinek. Available online: https://www.youtube.com/watch?v= qp0HIF3SfI4\&t=161s\&ab_channel=TED (accessed on 30 October 2020).

44. The Puzzle of Motivation|Dan Pink. Available online: https://www.youtube.com/watch?v=rrkrvAUbU9Y\& $\mathrm{t}=5$ s\&ab_channel=TED (accessed on 30 October 2020).

45. How to Speak So That People Want to Listen|Julian Treasure. Available online: https://www.youtube.com/ watch?v=eIho2S0ZahI\&ab_channel=TED (accessed on 30 October 2020).

46. What Makes a Good Life? Lessons from the Longest Study on Happiness|Robert Waldinger. Available online: https://www.youtube.com/watch?v=8KkKuTCFvzI\&ab_channel=TED (accessed on 30 October 2020).

47. How to Gain Control of Your Free Time|Laura Vanderkam. Available online: https://www.youtube.com/ watch? $\mathrm{v}=\mathrm{n} 3 \mathrm{kN1FMXslo \& ab \_ channel=TED}$ (accessed on 30 October 2020).

48. Ferrando, P.J.; Anguiano-Carrasco, C. El análisis factorial como técnica de investigación en psicología. Pap. Psicól. 2010, 31, 18-33.

49. Kaiser, H.F. A second generation little jiffy. Psychometrika 1970, 35, 401-415. [CrossRef]

50. Kaiser, H.F. The varimax criterion for analytic rotation in factor analysis. Pychometrika 1958, 23, $187-200$. [CrossRef]

51. Cronbach, L.J.; Shavelson, R.J. My current thoughts on coefficient alpha and successor procedures. Educ. Psychol. Meas. 2004, 64, 391-418. [CrossRef]

52. Cohen, J. Statistical Power Analysis for the Behavioral Sciences; Lawrence Erlbaum Associates: Hillsdale, NJ, USA, 1988.

53. Colomer, J.; Serra, L.; Cañabate, D.; Serra, T. Evaluating Knowledge and Assessment-Centered Reflective-Based Learning Approaches. Sustainability 2018, 10, 3122. [CrossRef]

Publisher's Note: MDPI stays neutral with regard to jurisdictional claims in published maps and institutional affiliations.

(C) 2020 by the authors. Licensee MDPI, Basel, Switzerland. This article is an open access article distributed under the terms and conditions of the Creative Commons Attribution (CC BY) license (http://creativecommons.org/licenses/by/4.0/). 